\title{
DÜBLIN
}

Technological University Dublin

ARROW@TU Dublin

\section{Efficacy of cold plasma functionalised water for improving microbiological safety of fresh produce and wash water recycling}

\author{
Apurva Patange \\ Technological University Dublin, apurva.patange@tudublin.ie \\ Peng Lu \\ Technological University Dublin \\ Daniela Boehm \\ Technological University Dublin, daniela.boehm@tudublin.ie
}

See next page for additional authors

Follow this and additional works at: https://arrow.tudublin.ie/schfsehart

Part of the Food Microbiology Commons, and the Food Processing Commons

\section{Recommended Citation \\ Apurva Patange, Peng Lu, Daniela Boehm, P.J. Cullen, Paula Bourke, Efficacy of cold plasma functionalised water for improving microbiological safety of fresh produce and wash water recycling, Food Microbiology, Volume 84, 2019, 103226, ISSN 0740-0020, DOI: 10.1016/j.fm.2019.05.010.}

This Article is brought to you for free and open access by the School of Food Science and Environmental Health at ARROW@TU Dublin. It has been accepted for inclusion in Articles by an authorized administrator of ARROW@TU Dublin. For more information, please contact arrow.admin@tudublin.ie, aisling.coyne@tudublin.ie, gerard.connolly@tudublin.ie.

Funder: Department of Agriculture Food and Marine; Science Foundation Ireland 


\section{Authors}

Apurva Patange, Peng Lu, Daniela Boehm, Patrick Cullen, and Paula Bourke 


\title{
Efficacy of cold plasma functionalised water for improving microbiological safety of fresh produce and wash water recycling
}

\author{
Apurva Patange ${ }^{\mathrm{a}}$, Peng Lu ${ }^{\mathrm{a}}$, Daniela Boehm ${ }^{\mathrm{a}}$, P.J. Cullen ${ }^{\mathrm{a}, \mathrm{b}}$, Paula Bourke ${ }^{\mathrm{a}, \mathrm{c}, *}$ \\ ${ }^{a}$ School of Food Science and Environmental Health, Technological University Dublin, Ireland \\ ${ }^{\mathrm{b}}$ School of Chemical Engineering, University of Sydney, Australia \\ ${ }^{\mathrm{c}}$ School of Biological Sciences, Queens University Belfast, Northern Ireland, United Kingdom
}

\section{A R T I C L E I N F O}

\section{Keywords:}

Aqueous atmospheric cold plasma

Minimally processed

Wash-water treatment

Microbial decontamination

\begin{abstract}
A B S T R A C T
Atmospheric cold plasma (ACP) is an effective method for microbiological decontamination. This study evaluated an alternative water-based decontamination approach for inactivation of bacterial population from fresh produce and in the wash water generated from fresh produce washing. The study characterised ACP inactivation of attached Listeria innocua and Pseudomonas fluorescens inoculated on lettuce in comparison to chlorine treatment. P. fluorescens was sensitive to ACP treatment and was reduced below detection limit within 3 min of treatment. $L$. innocua population was reduced by $\sim 2.4 \log _{10} \mathrm{CFU} / \mathrm{g}$ after 5 min of treatment; showing similar inactivation efficacy to chlorine treatment. The microbial load in wash water was continuously decreased and was below detection limits after $10 \mathrm{~min}$ of ACP treatment. Micro-bubbling along with agitation assisted the bacterial detachment and distribution of reactive species, thus increasing bacterial inactivation efficacy from fresh produce and wash water. A shift in $\mathrm{pH}$ of plasma functionalised water was observed along with high concentration of nitrate and ozone with a relative amount of nitrites which increased with plasma exposure time. Further, L. innocua treated at different independent $\mathrm{pH}$ conditions showed minimal or no effect of $\mathrm{pH}$ on ACP bacterial inactivation efficacy. Aqueous ACP treatment poses a promising alternative for decontamination of fresh produce and the associated wash-waters which could be applied in the food industry to replace continuous chlorine dosing of process waters.
\end{abstract}

\section{Introduction}

The role of fresh vegetables and fruits in providing nutrients and for a healthy diet is well recognized. However, as produce is often consumed raw, fresh produce can serve as a vehicle for many food-borne pathogens to survive and cause human infections. In 2016, a total of 4786 food-borne outbreaks, including waterborne outbreaks were reported in the EU alone, resulting in 49,950 cases of illness, 3869 hospitalizations and 20 deaths (EFSA, 2017).

The routes of fresh produce contamination are during growth in field, harvesting, post-harvest handling, washing or during storage and distribution. Some of the microbes are capable of colonizing, creating lesions and internalizing in healthy plant tissues. Internal tissues are rich in nutrients (water activity $>0.90$ ) and have neutral $\mathrm{pH}$ which provides the microorganism ideal conditions for microbial growth inside the produce (Barth et al., 2009). During the production of fresh cut or minimally processed fruits and vegetables, washing with water or different sanitizer solutions is a frequent method to loosen and remove dirt and disinfect produce. Efforts to resolve food safety problems linked to fresh or minimally processed produce are essential and timely, but should also consider end-user concerns, energy demands and the potential for toxicity. New non-residual chemical intervention technologies are needed to ensure microbial safety with minimum effects on sensory and nutritional quality of fresh produce.

Chlorine remains widely used for disinfection in fresh produce preparation. Although several reports have shown great efficiency of chlorine washes in eliminating bacterial populations, the practice of using a higher concentration of chemical sanitizers has raised concern regarding its possible generation of by-products and its impact on human health and environment (Gil et al., 2009; Van Haute et al., 2013). Atmospheric cold plasma is a novel technology which has attracted interest for disinfection of microbial population from different surfaces. The role of cold plasma from air at or near atmospheric pressure and room temperature has been extensively studied and has exhibited excellent antibacterial efficacy against target food pathogens and their spores and biofilms (Bourke et al., 2017). In-package 'dry'

\footnotetext{
* Corresponding author. Technological University Dublin, 31 Marlborough Street, Dublin 1, Ireland.

E-mail address: paula.bourke@dit.ie (P. Bourke).
} 
atmospheric cold plasma (ACP) treatment along with post treatment retention time of plasma reactive species has demonstrated bacterial inactivation efficacy for decontamination of fresh produce (Ziuzina et al., 2014). Besides antimicrobial activity of the gas plasma, application of plasma activated water has recently been introduced in bacterial inactivation studies for food safety (Ma et al., 2015; Schnabel et al., 2015). Until recently, plasma discharged water has been widely studied in the context of environmental and wastewater treatment (Cubas et al., 2016; Patange et al., 2018; Sarangapani et al., 2017). In this study, we investigated the inactivation efficacy and mechanism of plasma activated water against microbial populations on fresh produce. ACP generated using dielectric barrier discharge submerged in water was used in combination with co-axial diffusor assisted micro-bubble generation to disperse the plasma effluent through the treatment chamber. The plasma effluent is at the gas-liquid interface of the bubbles; which facilitates the transfer of oxidative species produced in the plasma directly to the liquid phase. Inatsu et al. (2013) demonstrated micro-bubbles increased oxidation efficiency of ozone which enhanced microbial collapse; micro-bubbles reduced Escherichia coli (E. coli) O157:H7 viability more than ozonated water on the surface of leafy vegetables.

The dissolution of plasma species in liquid phase triggers dynamic chemical reactions and forms several reactive species which are shortlived and difficult to detect. It has been well established that hydrogen peroxide, nitrates, and nitrites are longer-lived species and play important roles for biological effects (Guo et al., 2015). Consequently, quantitative detection of reactive species could serve as a useful indicator for plasma source characterization with regards to biological effects. One of the important advantages of employing a plasma discharge in water is in avoiding the damage that may be caused to a biological/sensitive product by charged particles, electrons, chemicals, and ultraviolet rays due to etching and degradation of bioactive compounds after the surface treatment (Thirumdas et al., 2018). This can be avoided by this liquid mediated indirect form of treatment, which makes it more suitable for study with fresh produce. The purpose of this study was to determine the efficacy of a submerged Dielectric Barrier Discharge plasma (DBD)-ACP system with diffusor assisted microbubbles against Listeria innocua and Pseudomonas fluorescens on fresh produce surface and for potential as a continuous process water decontamination treatment. Listeria spp. and Pseudomonas spp. are psychrotolerant and ubiquitous microorganisms that contaminate ReadyTo-Eat produce (Møretrø and Langsrud, 2017; Oliveira et al., 2011). The resistance of these species to chemical treatments aids their viability and infection potential in the environment. This research focuses on using alternative methods to remove these organisms from fresh produce as well as process wash water. L. innocua has been frequently proposed as a surrogate of $L$. monocytogenes because the two species are related closely phylogenetically (den Bakker et al., 2010; Glaser et al., 2001). Previous studies by Vaz-Velho et al. (2001) demonstrated comparable ozone resistance with $L$. innocua and $L$. monocytogenes, indicating $L$. innocua could be used as an appropriate surrogate for $L$. monocytogenes in experiments with reactive oxygen species as major inactivation factors. Since $L$. innocua is non-pathogenic, we employ this species directly in trials in custom built submerged DBD-ACP device, to investigate its persistence and sanitizer susceptibility rendering valuable data to predict L. monocytogenes behaviour without causing contamination issues.

The studies also compared the independent and combined effects on bacterial inactivation of cold plasma micro bubbling and agitation, micro-bubbling and agitation in deionized water without cold plasma to treatment with chlorinated water set at a standard chlorine concentration $(100 \mathrm{ppm})$. Of importance for practical application and to establish potential as a replacement technology for chlorine assisted decontamination, the efficacy of ACP to reduce bacterial load transferred from lettuce wash into wash water was also investigated.

\section{Materials and methods}

\subsection{Strain and inoculum preparation}

Pseudomonas fluorescens LZB065 and Listeria innocua NCTC 11288 was obtained from the microbiology stock culture of the School of Food Science and Environmental Health of the Dublin Institute of Technology. Both stock cultures were maintained in the form of protective beads at $-70{ }^{\circ} \mathrm{C}$. One protective bead of culture of $P$. fluorescens and $L$. innocua was streaked onto separate tryptic soy agar (TSA, Biokar Diagnostics, France) plate and incubated at $30^{\circ} \mathrm{C} \& 37^{\circ} \mathrm{C}$, respectively for $24 \mathrm{~h}$. The plates were further maintained at $4^{\circ} \mathrm{C}$.

A single colony was inoculated into tryptic soy broth (Scharlau Chemie, Barcelona, Spain) and incubated overnight $(18 \mathrm{~h})$. Bacteria were washed thrice with phosphate buffer saline (1X PBS, Oxoid LTD, UK) by centrifugation at $10,000 \times g$ for $5 \mathrm{~min}$. The final bacteria concentration was adjusted using 0.5 McFarland standard (BioMerieux, Marcyl'Etoile, France) and confirmed by plating on TSA (approx. 7-8 $\log _{10} \mathrm{CFU} / \mathrm{mL}$ ).

\subsection{Produce preparation}

Fresh iceberg lettuce was purchased from the local supermarket on the day of the experiment and stored $4{ }^{\circ} \mathrm{C}$ until use. The outermost leaves of the lettuce were removed and the next layers of leaves were detached and used for the experiments. Lettuce pieces were cut $(5 \times 5 \mathrm{~cm})$ aseptically and rinsed with sterile distilled water to clean and to remove unattached bacteria. Washed lettuce samples were dried in bio-safety cabinet for $20 \mathrm{~min}$. For lettuce inoculation, $100 \mu \mathrm{L}$ of prepared bacterial suspension was spot inoculated and dried in biosafety cabinet with air flow for $2 \mathrm{~h}$ to promote attachment. The samples were then transferred to sterile containers and stored for 0 or $24 \mathrm{~h}$ at $4{ }^{\circ} \mathrm{C}$.

\subsection{ACP system}

Fig. 1(a) shows the schematics of atmospheric cold plasma (ACP) treatment system used in this study. The ACP treatment system is based on a submerged DBD plasma source. The submerged DBD plasma source employs a conventional coaxial electrode configuration which is submerged into the liquid and held in the direction required. The custom built high voltage electrode is sealed in a quartz tube (NUOK LTD, Hong Kong), and the ground electrode is inserted into the liquid. The gap between the two coaxial quartz tubes was $2 \mathrm{~mm}$. The liquid serves as both an additional dielectric barrier layer and the coolant for the discharge. Therefore, the plasma column length is determined by the depth of the liquid in the beaker. In this study, the liquid was contained in a cylindrical borosilicate glass beaker (internal diameter of $100 \mathrm{~mm}$ and height $135 \mathrm{~mm}$ - Thermo-fisher Ltd, Ireland) with a total volume of $800 \mathrm{~mL}$. Air was the plasma working gas and its flow rate controlled by a mass flow controller (KOFLOC DF300C). The diffusion of the post-discharge afterglow plasma effluent into the liquid was assisted using four ceramic gas diffusers attached at the end of the tubes. These gas diffusors generated micro-bubbles, leading to both agitation and the distribution of the plasma effluent in the open cylindrical container. The plasma discharge is driven by a high voltage (HV) AC power supply (PVM500, Information Unlimited). Applied voltage and discharge current were monitored by a HV probe (Tektronix P6015A) and a wideband current transformer (Stangenes Industries CT $0.5 \mathrm{~W}$ ), respectively. Lissajous Q-V figure was measured to calculate the DBD plasma power. The measurement capacitance is $4.7 \mathrm{nF}$. Fig. 2 (a) shows the waveforms of applied voltage, plasma current, and voltage across the measurement capacitor, the frequency of the applied voltage is $25.8 \mathrm{kHz}$. Fig. 2 (b) shows the Lissajous Q-V figure of the single discharge period, from which it is calculated that the average DBD power is about $7.45 \mathrm{~W}$. 


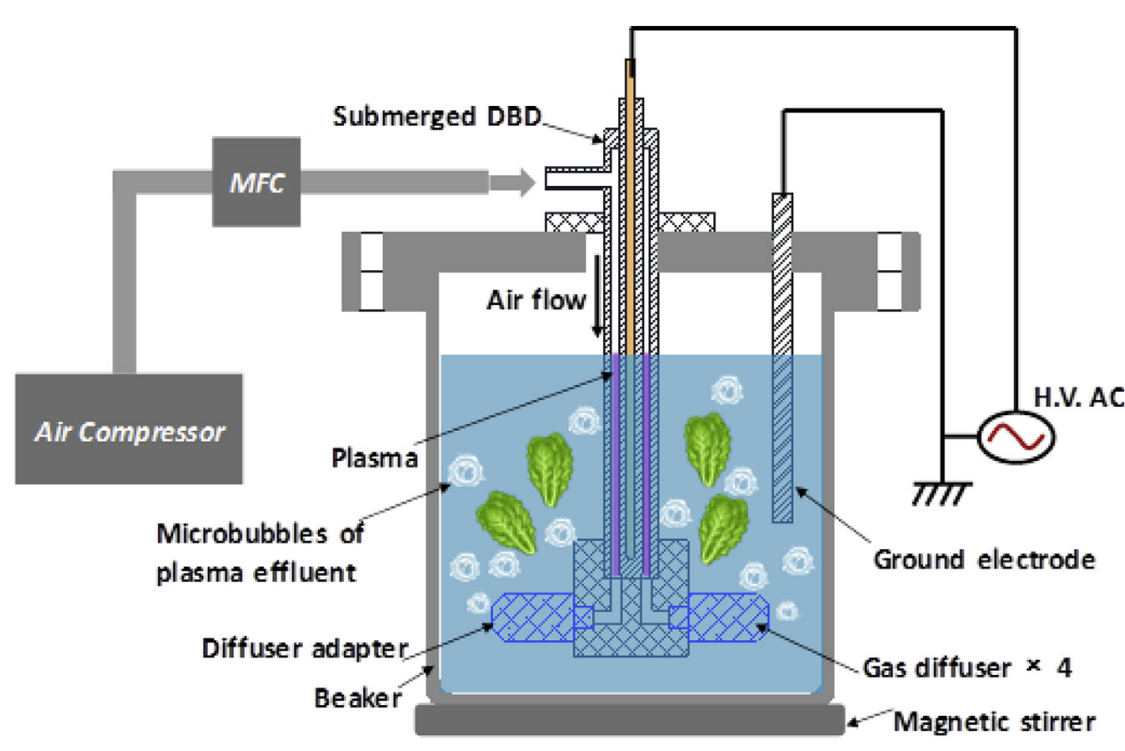

(a)

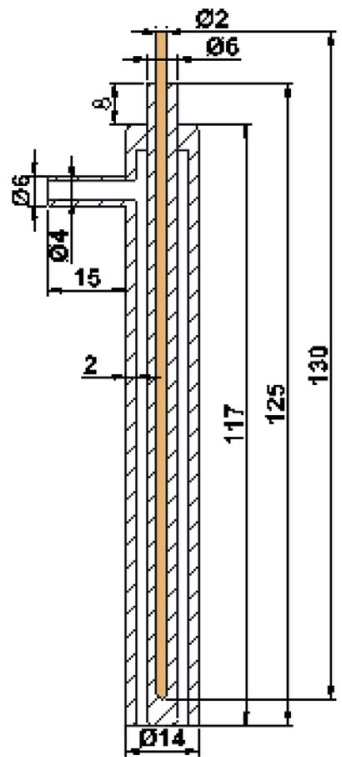

(b)

Fig. 1. The experimental setup for treatment of lettuce and wash-water using Submerged DBD-ACP system: (a) system setup, (b) geometry of submerged DBD plasma source.

The diffusion of the micro-bubbles was further assisted using a magnetic stirrer at an approximate speed of $450 \mathrm{rpm}$ (IKA C-MAG HS 7). Plasma treatment was operated at voltage of $20 \mathrm{kV}$ for treatment periods of $0-10 \mathrm{~min}$. The temperature of the plasma functionalised water was continuously monitored and remained below $30^{\circ} \mathrm{C}$. For each treatment, five inoculated lettuce samples were immersed in the submerged discharge plasma reactor containing $700 \mathrm{~mL}$ of sterile distilled water. The ratio of vegetable sample to plasma functionalised wash water was $15 \mathrm{~g}-700 \mathrm{~mL}(\sim 1: 50)$.

\subsection{Microbiological analysis}

Microbiological analysis was carried out immediately after processing. Lettuce samples were aseptically cut and $10 \mathrm{~g}$ portions of lettuce (treated/control) were stomached with $10 \mathrm{~mL}$ of sterile maximum recovery diluent (MRD, Scharlau Chemie, Spain) for $3 \mathrm{~min}$. Bacterial populations attached to lettuce at time point 0 was 6.2 and $6.8 \mathrm{Log} \mathrm{cfu} /$ g of $L$. innocua and $P$. fluorescens respectively and samples treated with sterile distilled water temporarily bubbling of untreated water without plasma forming was the negative control.

Appropriate dilutions were made and plated onto Palcam agar (Scharlau Chemie, Spain) supplemented with Palcam Listeria Selective Supplement (Oxoid Ltd, England) for $L$. innocua and onto Pseudomonas Agar Base (PAB, Oxoid, England) supplemented with Cetrimide Fucidin Cephalosporin (CFC, Oxoid Ltd, England) for P. fluorescens. Results were expressed as $\log _{10}$ colony forming units per gram (CFU/g). Wash water samples were assessed to measure the surviving bacterial populations remaining water. Viable bacteria were enumerated according to Standard Methods for Examination of Water and Wastewater (APHA, 2012) by membrane filtration method. Results for wash water analysis are represented in $\log _{10}$ colony forming unit (CFU) per $10 \mathrm{~mL}$ on TSA and selective agar plates.

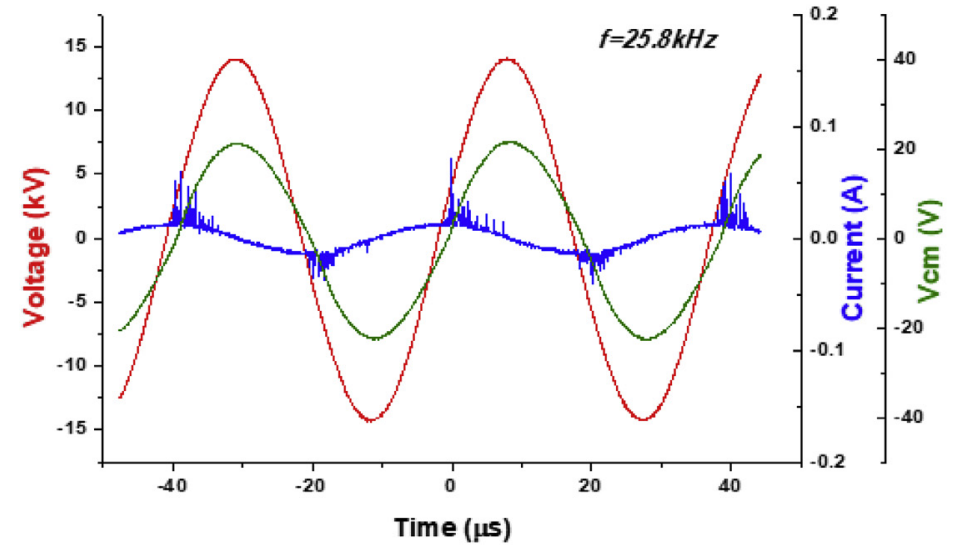

(a)

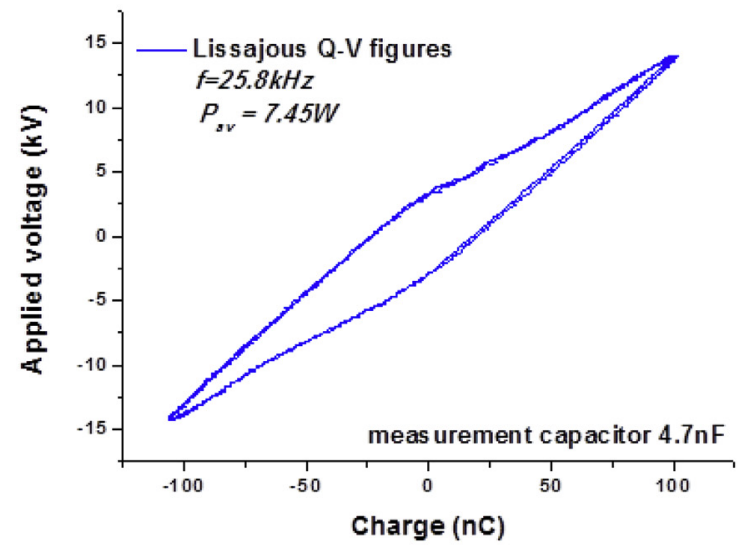

(b)

Fig. 2. (a) Waveforms of applied voltage, discharge total current and voltage across the measurement capacitor, (b) Lissajous Q-V figure for energy consumption measurement in one period of applied voltage. 


\subsection{Antimicrobial effect of the independent $\mathrm{pH}$ control}

ACP treatment is known to cause a reduction in $\mathrm{pH}$ from neutral to acid, therefore to determine the extent to which acidification was responsible for the observed antimicrobial activity, a $\mathrm{pH}$ control experiment was performed. Lettuce inoculated with $L$. innocua was exposed to different acidic conditions ( $\mathrm{pH} 3-5$ ) for exposure time equivalent to those of the plasma functionalised wash water. The working solution was prepared by adding $1 \mathrm{~N}$ Hydrochloric acid $(\mathrm{HCl})$ to sterile deionized water and adjusting the $\mathrm{pH}$ to 3,4 and 5 . The prepared acid solutions were then exposed to the same ratio of vegetable to water $(\sim 1: 50)$ of $10^{7-8} \mathrm{CFU} / \mathrm{mL}$ L. innocua and held for $0-10 \mathrm{~min}$ in submerged DBD system with micro-bubbling and agitation without plasma treatment. Colony count assay was performed for quantification of surviving bacteria as described previously.

\subsection{Scanning electron microscopy (SEM) analysis}

Samples treated with ACP treatment with $L$. innocua and $P$. fluorescens attached on lettuce piece were analysed by SEM. SEM sample processing was performed as described by Ziuzina et al. (2015) with minor modifications. The treated/untreated lettuce samples were cut in $1 \times 1 \mathrm{~cm}$ pieces and immersed in aliquots of $2.5 \%$ glutaraldehyde (Sigma Aldrich, Ireland) in $0.05 \mathrm{M}$ sodium cacodylate buffer ( $\mathrm{pH} 7.4$ ) (SCB, Sigma Aldrich, Ireland) for overnight. The samples were then washed with SCB three times and fixed with $1 \%$ osmium tetroxide (Sigma Aldrich, Ireland) for $2 \mathrm{~h}$ at $4{ }^{\circ} \mathrm{C}$. After $2 \mathrm{~h}$ fixing, the samples were washed with the same buffer followed by washing with sterile distilled water for three times. The samples were subjected to series of dehydration process with ethanol solutions $(30 \%, 50 \%, 70 \%, 80 \%$, $95 \%$, and $99.5 \%$ ) followed by dehydration with $33 \%, 50 \%, 66 \%$, and $100 \%$ of hexamethyldisilazane (Sigma Aldrich, Ireland). The dried samples were then sputter-coated with gold particles using Emitech K575X Sputter Coating Unit resulting in a coating of $10 \mathrm{~nm}$ after $30 \mathrm{~s}$. The samples were examined visually using a FEI Quanta 3D FEG Dual Beam SEM (FEI Ltd., Hillsboro, USA) at $5 \mathrm{kV}$.

\subsection{Detection of reactive species}

Hydrogen peroxide concentrations in plasma treated water were determined using oxidation of potassium iodide to iodine and spectrophotometric measurement at $390 \mathrm{~nm}$. A standard curve of known hydrogen peroxide concentrations was included on each plate and used to convert absorbance into peroxide concentrations. Nitrite concentrations were determined using Griess reagent and spectrophotometric measurement at $548 \mathrm{~nm}$ after $30 \mathrm{~min}$ incubation and compared to a sodium nitrite standard curve. Nitrate concentrations were assessed by 2,6-dimethyl using the Spectroquant nitrate assay kit (Merck Chemicals, Darmstadt, Germany). Further dissolved ozone concentration was measured by the indigo method as described in Bader and Hoigne (1981).

\subsection{Chlorine treatment}

Sodium hypochlorite solution and its derivatives are commonly used for sanitizing fresh produce (Warriner et al., 2009) and in fact, chlorine is a very potent disinfectant with powerful oxidizing properties (Suslow, 1997). High concentrations of sanitizers $(100-300 \mathrm{mg} / \mathrm{L}$ ) are commonly applied in the food industry (Beuchat, 1998; MartínezHernández et al., 2015). Chlorinated water was included as the standard washing agent for comparison in terms of efficacy and prepared by adding sodium hypochlorite $(\mathrm{NaOCl})$ solution containing $6-14 \%$ active chlorine (EMPLURA ${ }^{\circ}$ Sigma-Aldrich Ireland Ltd) to sterile distilled water to obtain concentrations of $100 \mathrm{mg} / \mathrm{L}$ free chlorine. The $\mathrm{pH}$ of the washing solutions was adjusted to 7.1-7.3 using $1 \mathrm{M}$ hydrochloric acid. The treatment set up and sample analysis were the same as described for ACP treatment, but plasma was not turned on.

\subsection{Statistical analysis}

Each experiment was repeated three times. Statistical mean differences between various treatment groups and controls were compared using a one-way ANOVA using GraphPad Prism 5 (GraphPad Software, La Jolla California USA). Statistical differences among the treatments were performed using Tukey pairwise comparison test. Results were considered significant at $\mathrm{p} \leq 0.05$.

\section{Results and discussion}

Fresh produce can be contaminated with a range of bacterial population which can pose a serious health risk as this category of product are prepared, distributed, stored and consumed raw. Produce washing is widely used method to minimize the microbial risk and maintain the quality of raw fresh produce from farm to consumer food chain. The efficacy of plasma treatment to control microorganisms is dependent on many systems and process related parameters including inducer gas, the geometry of the system and the type of device used; thus, the key antimicrobial effectors and resulting efficacy may also differ (Han et al., 2016; Liao et al., 2017). This study demonstrated the use of a submerged dielectric barrier discharge into water assisted by coaxial diffusers in addition to the agitation of micro-bubbles to indirectly treat fresh produce with plasma functionalised water.

\subsection{Inactivation of P. fluorescens on fresh lettuce}

Lettuce inoculated with $P$. fluorescens and refrigerated for $24 \mathrm{~h}$ to allow attachment was treated with plasma functionalised water in the treatment chamber. Efficacy in relation to agitation on or agitation off was compared. High speed agitation using magnetic stirrer enhanced the ability of the plasma to inactivate bacteria on lettuce surface (Fig. 3). The purpose of washing fresh produce is to remove dirt and loosen microbial attachment to surfaces so they may be removed or subject to the action of any additive treatment within the water. High speed agitation may help distribute the plasma reactive species in the reaction mixture generated from plasma treatment, thus helping to remove and inactivate firmly attached microbial cells present at

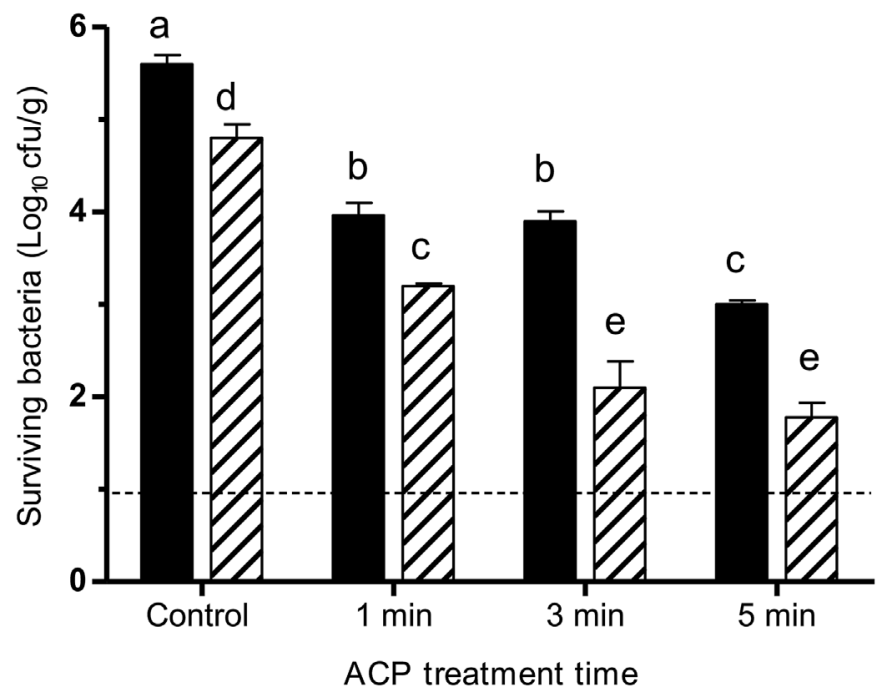

Fig. 3. Effect of ACP $(\mathbb{N})$ with or ( $)$ without agitation on viable counts of $P$. fluorescens inoculated on lettuce. Vertical bars indicate standard deviation. Dotted lines indicate limit of detection ( $1 \log _{10} \mathrm{CFU} / \mathrm{g}$ ). Column with different letters indicate a significant difference between treatment method and treatment time $(\mathrm{p}<0.05)$. 
different niches on lettuce surface. Moreover, previous studies have demonstrated pre-treatment with sanitizers using micro-bubbles generation improved the bactericidal effect for decontamination of fresh produce (Kim et al., 1999; Soli et al., 2010). Micro-bubbles have demonstrated high stability and surface areas that can maintain ozone, which may improve antimicrobial efficacy. Marui (2013) demonstrated small micro-bubble increased the dissolved potential of ozone and free radicals by cracking of the bubbles. Diffusor assisted bubbling of plasma generated effluent in conjunction with high speed stirrer agitation was efficient and was selected for further experiment conditions.

\subsection{Antimicrobial effect of micro-bubbling plasma functionalised water on} lettuce

The effect of ACP on the microbial load attached on iceberg lettuce was assessed, and challenge microorganisms allowed to attach for $1 \mathrm{~h}$ and $24 \mathrm{~h}$ were compared. As a control, washing the lettuce with sterile deionized water with no bubbling yielded approx. 1-0.5 $\log _{10} \mathrm{CFU} / \mathrm{g}$ reduction after $10 \mathrm{~min}$ (Table S1). Plasma bubbling into the produce treatment chamber was also compared with bubbling without plasma discharge, and it was observed that plasma bubbling increased the antimicrobial efficacy for lettuce samples significantly by comparison with bubbling of untreated water alone; Fig. 4 ( $p<0.05$ ). Washing with untreated water had limited efficacy for microbial reduction regardless of the washing time. Values represent the average population recovered with a detection limit of $1 \log _{10} \mathrm{CFU} / \mathrm{g}$. The inactivation pattern for $P$. fluorescens population inoculated on lettuce followed a linear trend, showing significant reduction during 1-10 min of ACP treatment $(\mathrm{p}<0.05)$. In the case of $L$. innocua a significant reduction of $1.9-2 \log _{10} \mathrm{CFU} / \mathrm{g}$ was observed after $3 \mathrm{~min}$ of ACP treatment; however, survival curves for L. innocua showed a tailing effect even after increasing the treatment time to $10 \mathrm{~min}$.

Gram negative bacteria have been shown to be more susceptible to ACP than Gram positive bacteria due to differences in cell wall structure (Mai-Prochnow et al., 2016). The thick peptidoglycan layer of the Gram positive bacteria poses a barrier for plasma reactive species to penetrate through the cell wall and impacts its antimicrobial efficacy. This agrees with our study where despite similar initial inoculation levels on lettuce surface, $P$. fluorescens decreased significantly in number after exposure to ACP treatment compared to $L$. innocua. In addition to target cell characteristics, the stage, strength, and nature of bacterial attachment to produce may also impact overall ACP inactivation efficacy. Some foodborne pathogens attach and internalize into plant tissue thus contributing to elevated resistance to antimicrobial agents. Rough food surfaces or those characterised by stomata or seeds on surfaces present protective niches requiring longer treatment times. SEM micrographs of lettuce surface show that treatment with plasma functionalised water for 1 and $3 \mathrm{~min}$ did not lead to any visible damaging effect on the lettuce surface (Fig. 5), while significantly decreasing the bacterial population. Changes in the bacterial morphology were observed, showing damaging effect after $1 \mathrm{~min}$ of plasma treatment in the case of $P$. fluorescens and after $3 \mathrm{~min}$ of treatment, the lettuce integrity was maintained whilst $P$. fluorescens populations remaining were at the detection limit.

\subsection{Wash water analysis}

Contaminated produce wash water can be a vehicle for microbial cross-contamination through the transfer of microbial contaminants; usually requiring removal from process or addition of chemicals to decontaminate the water prior to re-use. Developing a chemical free intervention to enhance the safe recycle-ability of wash water is an important step for water and energy sustainability as well as microbiological safety. The surviving bacterial load released from lettuce to the process effluent is illustrated in Fig. 6. Continuous bubbling and agitation of plasma effluent through the process water reduced the

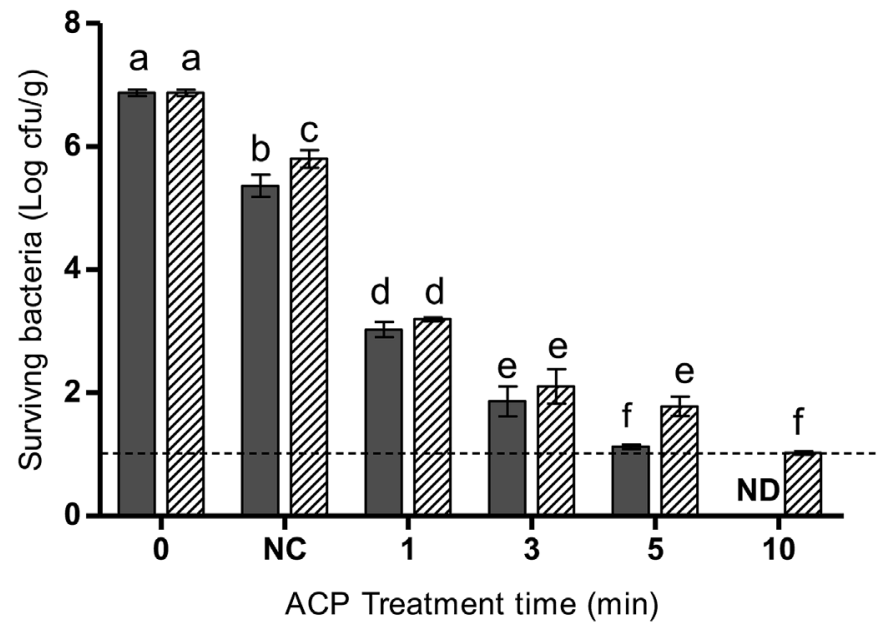

(a)

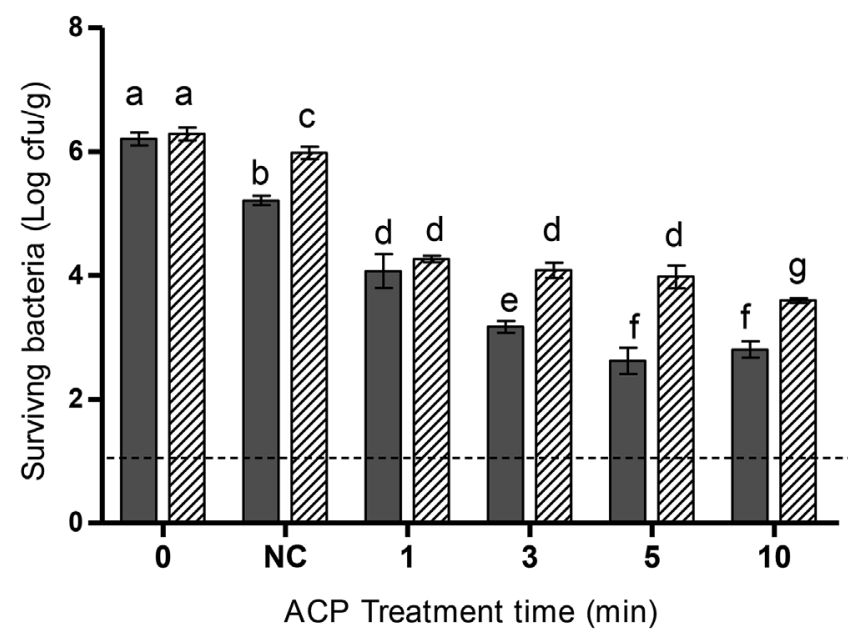

(b)

Fig. 4. Effect of ACP on (a) P. fluorescens (b) L. innocua attached to lettuce leaves for $(\mathbb{\square}) 1 \mathrm{~h}$ and $(\mathbb{\mathbb { N }}) 24 \mathrm{~h}$. Each column represents average bacterial population recovered after ACP treatment. Vertical bars indicate standard deviation. Dotted line indicates limit of detection $1.0 \log _{10} \mathrm{CFU} / \mathrm{g}$. NC: Negative control; ND: Not detected (counts below detection limit). Column with different letters indicate a significant difference between bacterial attachment and treatment time $(\mathrm{p}<0.05)$.

survival of microbes released into the process effluent. The microbial load in wash water declined continuously and was below the detection limit for $P$. fluorescens after 10 min contact time with plasma generated reactive species. Limitations associated with common chemical disinfectants include minimal efficacy, operational costs, the safety management of the technology at the processing site, formation of hazardous by-products and the need for monitoring ambient concentration levels (Van Haute et al., 2015). In the case of ACP treatment, the continuous generation of plasma reactive species in the wash water provides a reservoir of active agent that can overcome scavenging by organic debris or contaminants and can also serve as a continuous treatment to either clean or refunctionalise wash water during and after the produce processing. This is advantageous from both cost and water sustainability perspectives.

\subsection{Effect of $p H$}

Fig. 7 illustrates the changes in $\mathrm{pH}$ of the samples after plasma 
a) Pseudomonas fluorescens

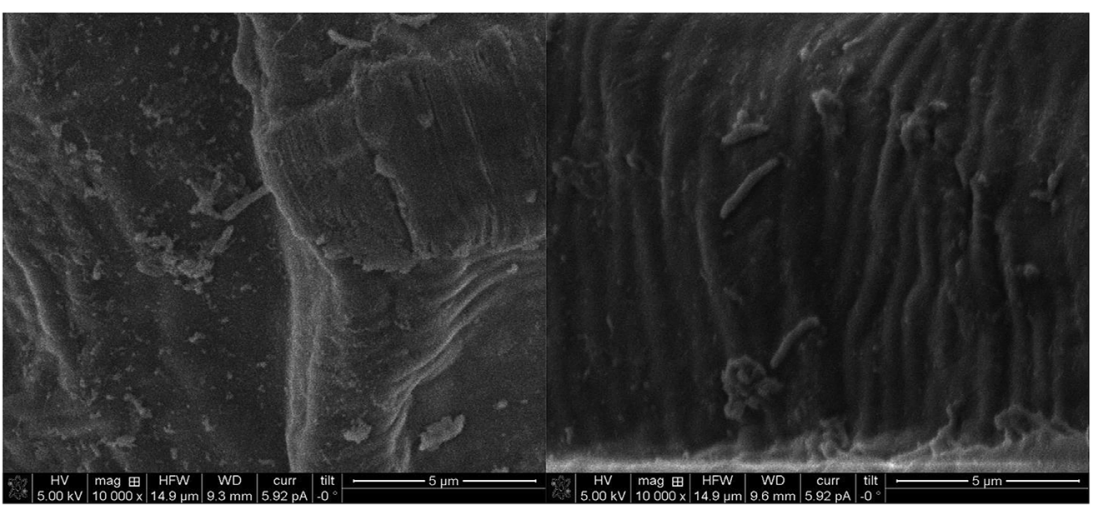

I] After water wash (Control)

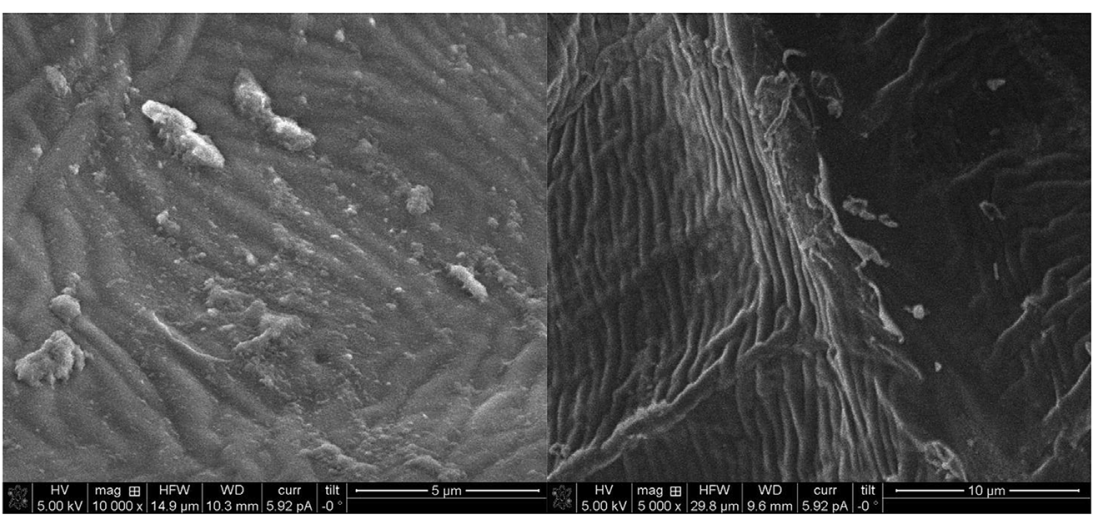

II] 1 min ACP functionalised water treatment
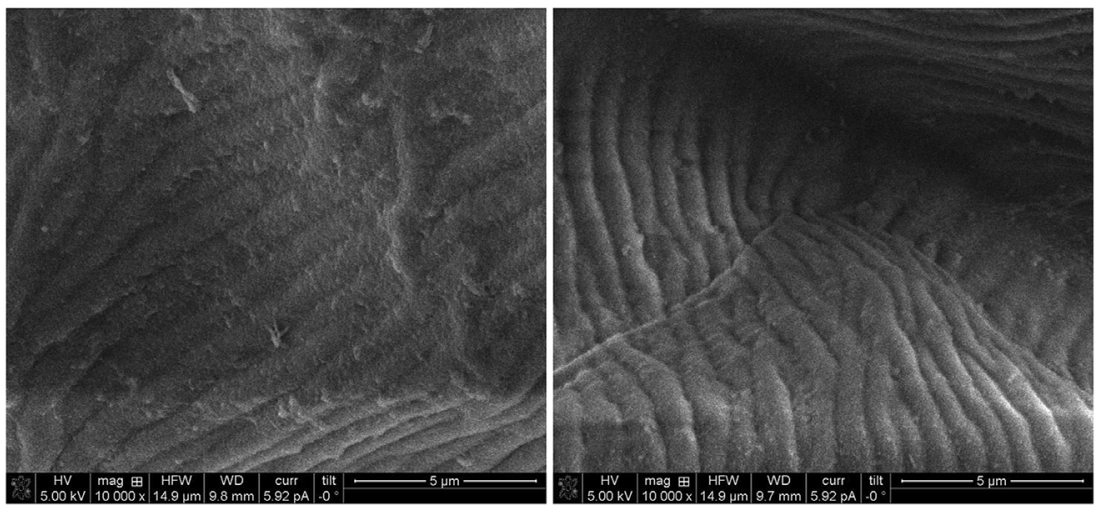

III] 3 min ACP functionalised water treatment

Fig. 5. SEM images of (a) P. fluorescens (b) L. innocua inoculated on lettuce; (I) Untreated control after water-wash, (II) 1 min ACP treatment and (III) 3 min ACP treatment.

treatment. The initial $\mathrm{pH}$ of water used for treatment was $7.2 \pm 0.1$, which decreased with increasing plasma treatment time. The shift in $\mathrm{pH}$ can be attributed to the production of acids including nitrates, nitrites and hydrogen peroxides (Oehmigen et al., 2010). Similar results were obtained where plasma discharges lead to acidification of treated water (Lu et al., 2017; Traylor et al., 2011). Lower pH is favourable for reactive species to penetrate the cell wall, further affecting bacterial membrane system (Bourke et al., 2017; Ikawa et al., 2010). To account for any independent effect of the acidic conditions, L. innocua was treated at different $\mathrm{pH}$ conditions. The bacterial inactivation was nonsignificant at the different $\mathrm{pH}$ conditions equivalent to those generated by $1,3,5$ or $10 \mathrm{~min}$ of plasma treatment (Fig. 8), with the exception of
$\mathrm{pH} 5$; where the bacterial population was reduced by $1.3 \pm 0.13$ $\log _{10} \mathrm{CFU} / \mathrm{g}$ after $10 \mathrm{~min}$ treatment time. Satoh et al. (2007) reported that inactivation of $E$. coli in an acidified liquid ( $\mathrm{pH} 3.4$ ) needed a longer period of time compared to plasma treatment. However, others have demonstrated that an acidic environment along with the addition of nitrate ions or hydrogen peroxide could not induce significant inactivation of microorganisms comparable to plasma treatment (Ercan et al., 2013; Oehmigen et al., 2010). The acidic environment alone did not have significant bacterial inactivation properties for the contact times used in this study; however, the acid conditions generated may be complementary to the action of plasma functionalised water. 


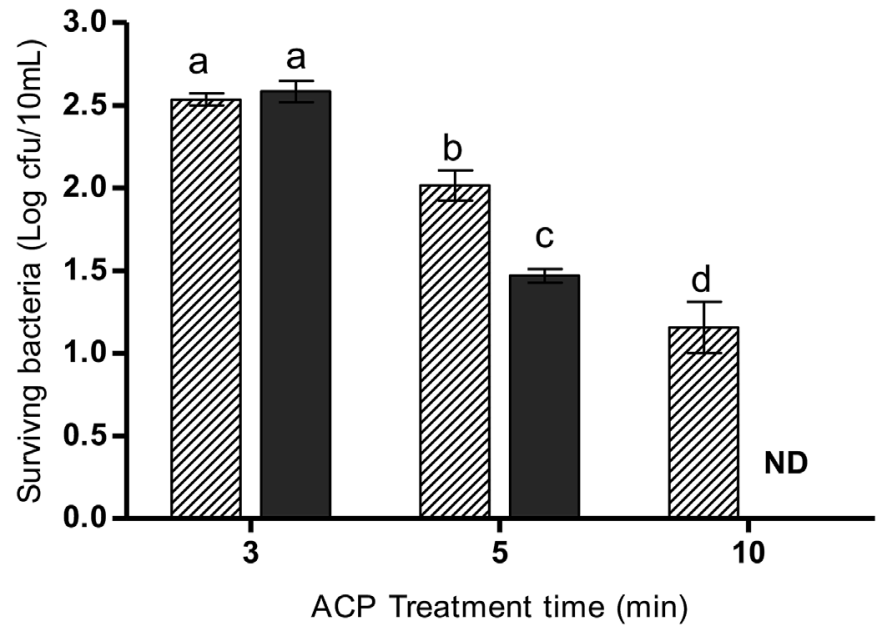

Fig. 6. Survival of $(\mathbb{N})$ L. innocua and (⿴) P. fluorescens in the wash water after washing lettuce in plasma functionalised water. ND: not detected (below detection limit of $1 \mathrm{Log}$ CFU/10 mL); Vertical bars indicate standard deviation. Column with different letters indicate a significant difference between bacteria and treatment time $(\mathrm{p}<0.05)$.

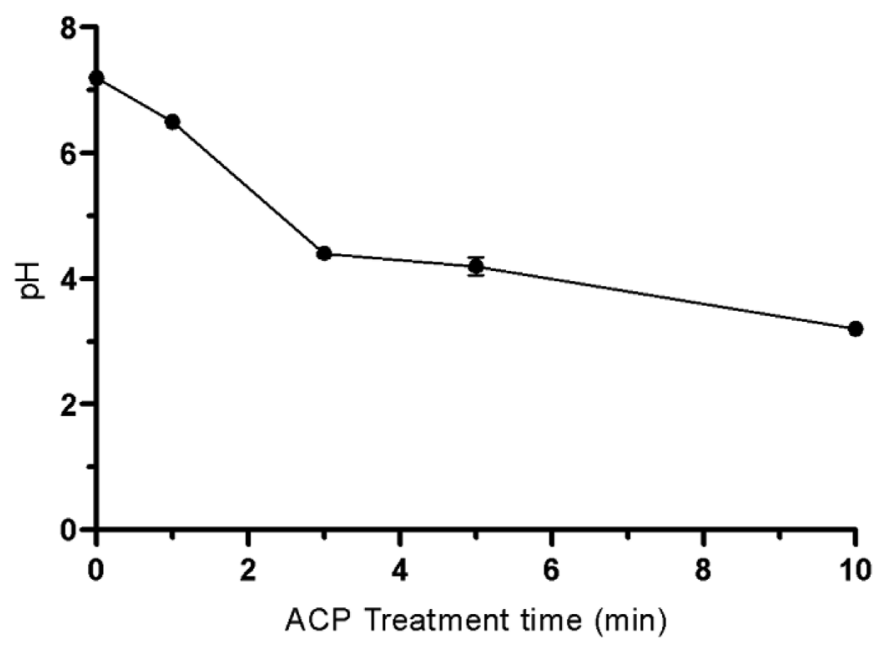

Fig. 7. $\mathrm{pH}$ value of wash water after DBD-ACP treatment.

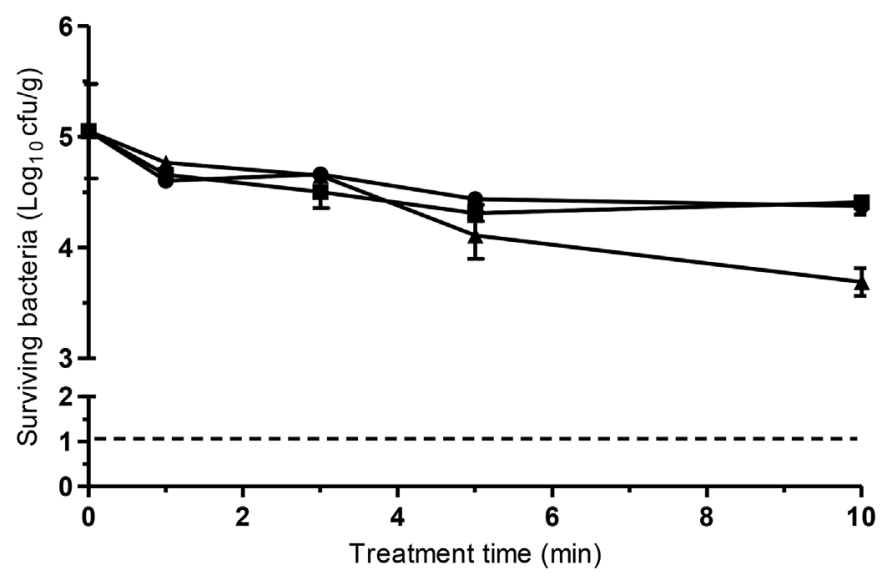

Fig. 8. Bacterial inactivation assay in acidic solutions. L. innocua $\left(10^{7-8} \mathrm{CFU} /\right.$ $\mathrm{mL}$ ) inoculated on lettuce exposed to different acidic conditions ( $\mathbf{0}) \mathrm{pH} \mathrm{3,(0)}$ $\mathrm{pH} 4$ and $(\mathbf{\Delta}) \mathrm{pH}$ 5. Dotted line indicates detection limit (1.0 Log CFU/g). Vertical bars indicate standard deviation. Column with different letters indicate a significant difference between $L$. innocua treated in different $\mathrm{pH}$ solutions and treatment time $(\mathrm{p}<0.05)$.

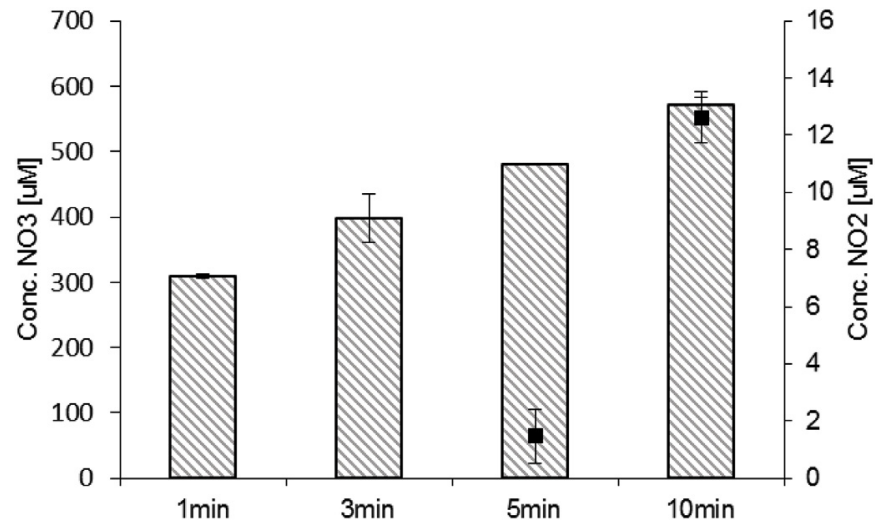

Fig. 9. Concentration of $(\mathbb{N})$ Nitrate and ( $\mathbf{})$ Nitrite reactive species in plasma functionalised water. Vertical bars represent standard deviation. Experimental conditions: $1,3,5$ and $10 \mathrm{~min}$ treatment at $80 \mathrm{kV}$ with $0 \mathrm{~h}$ post treatment storage time.

\subsection{Chemical analysis}

3.5.1. Measurement of hydrogen peroxide, nitrite, and nitrate concentrations

Plasma discharged in water produces reactive species such as superoxide, the hydroxyl radical, singlet oxygen, and nitric oxide (Schmidt-Bleker et al., 2016). These short-lived species are converted rapidly to relatively longer lived species such as hydrogen peroxide, nitrites, nitrates and other uncertain intermediate species (Shimizu et al., 2011). These diverse RONS play an important role in antimicrobial activity (Joshi et al., 2011). The concentration of hydrogen peroxide $\left(\mathrm{H}_{2} \mathrm{O}_{2}\right)$, nitrate $\left(\mathrm{NO}_{3}{ }^{-}\right)$and nitrite $\left(\mathrm{NO}_{2}{ }^{-}\right)$reactive species generated after ACP treatment in water is presented in Fig. 9. The plasma functionalised water generated using this submerged DBD diffuser contained higher concentrations of nitrate but no detectable levels of hydrogen peroxide. The concentration of nitrate increased with respect to treatment time in the range of $250-400 \mu \mathrm{M}$. However, a very low concentration of $12.63 \mu \mathrm{M}$ nitrite was detected only after $10 \mathrm{~min}$ of ACP treatment.

The concentration of dissolved ozone concentration in water was measured by the indigo degradation method. Ozone is another long lived ROS generated by atmospheric cold plasma discharge and is a powerful oxidant, capable of inactivating various classes of pathogens. ACP treatment for $90 \mathrm{~s}$ increased the ozone concentration to $6 \mathrm{mg} / \mathrm{L}$, but this remained constant after $120 \mathrm{~s}$ exposure time (Fig. 10). The reactive species content in the plasma functionalised water indicated increased concentrations of nitrate and ozone with increasing plasma treatment time, with some nitrite detectable at $10 \mathrm{~min}$. The type and concentration of RONS generated by plasma system depends on several factors including plasma-liquid interactions at the liquid surface (sputtering, high electric field induced hydrated ion emission, and evaporation), plasma source, discharge setup, gases and liquids used for treatment (Lukes et al., 2014). Each plasma system offers differing reactive species composition, with diverse antimicrobial and cytotoxic activities, which points to the need for target or function led design of the appropriate plasma functionalised liquid.

\subsection{Comparison of plasma functionalised water with sodium hypochlorite washing for bacterial reduction on lettuce}

Sodium hypochlorite solution and its derivatives are commonly used for sanitizing fresh produce (Warriner et al., 2009). The effectiveness of ACP was compared to commonly used $\mathrm{NaOCl}$ for decontamination of $L$. innocua and $P$. fluorescens attached on lettuce. The initial number of $L$. innocua and $P$. fluorescens attached to lettuce leaves was 5.2-5.6 $\log _{10} \mathrm{CFU} / \mathrm{g}$ and 5.0-5.4 $\log _{10} \mathrm{CFU} / \mathrm{g}$, respectively. Both the 


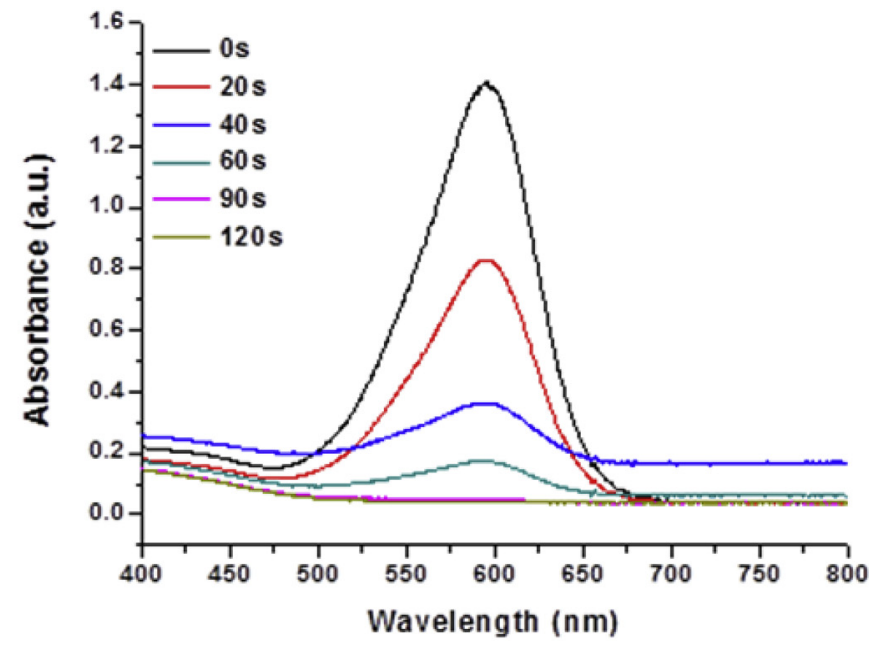

(a)

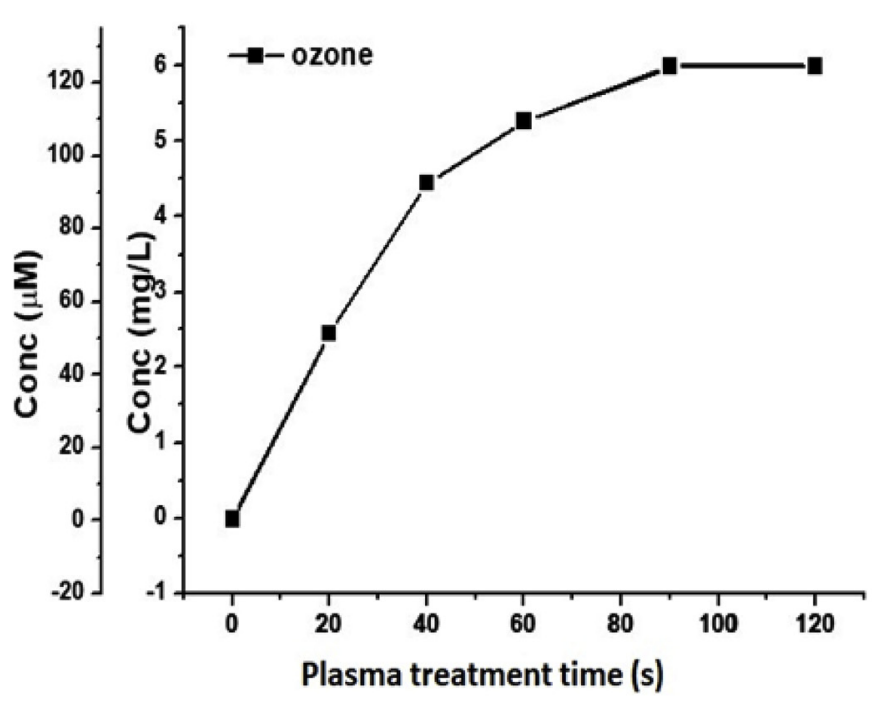

(b)

Fig. 10. (a) Absorption spectra of Indigo Reagent degradation by DBD-ACP Liquid Treatment System and (b) Concentrations of dissolved ozone in water generated during plasma exposure time.

treatments caused a significant reduction in bacterial counts when compared to corresponding controls. For $L$. innocua, both treatments (chlorine and ACP) showed a similar reduction of 2.4-2.9 $\log _{10} \mathrm{CFU} / \mathrm{g}$ on lettuce after increasing the treatment time to $10 \mathrm{~min}(\mathrm{p}>0.05)$. However, greater reduction in $P$. fluorescens population was observed with plasma water washing when compared to chlorine wash. With the same exposure duration, $100 \mathrm{mg} / \mathrm{L}$ chlorine wash achieved reduction of $4 \log _{10} \mathrm{CFU} / \mathrm{g}$ while ACP treatment reduced the $P$. fluorescens population below the detection limit (Fig. 11).

The disinfection efficiency of chlorine washes varies; for example, sanitizing with $0.02 \%$ sodium hypochlorite $(200 \mathrm{mg} / \mathrm{L}$ free chlorine) reduced background microbiota on strawberry, cherry tomato, and red bayberry by approximately $0.20-2.07 \log \mathrm{CFU} / \mathrm{g}$ (Wei et al., 2017). Other studies reported $0.76 \log \mathrm{CFU} / \mathrm{g}, 0.79 \mathrm{log} \mathrm{CFU} / \mathrm{g}$, and $0.47 \mathrm{log}$ $\mathrm{CFU} / \mathrm{g}$ log reductions of initial coliform from fresh-cut radishes, zucchini, and green bell peppers after washing with $100 \mathrm{mg} / \mathrm{L}$ sodium hypochlorite (Sun et al., 2012). Although chlorine is commonly applied as a disinfectant in washing fresh produce, a challenge is to maintain a stable free chlorine concentration during washing, necessitating

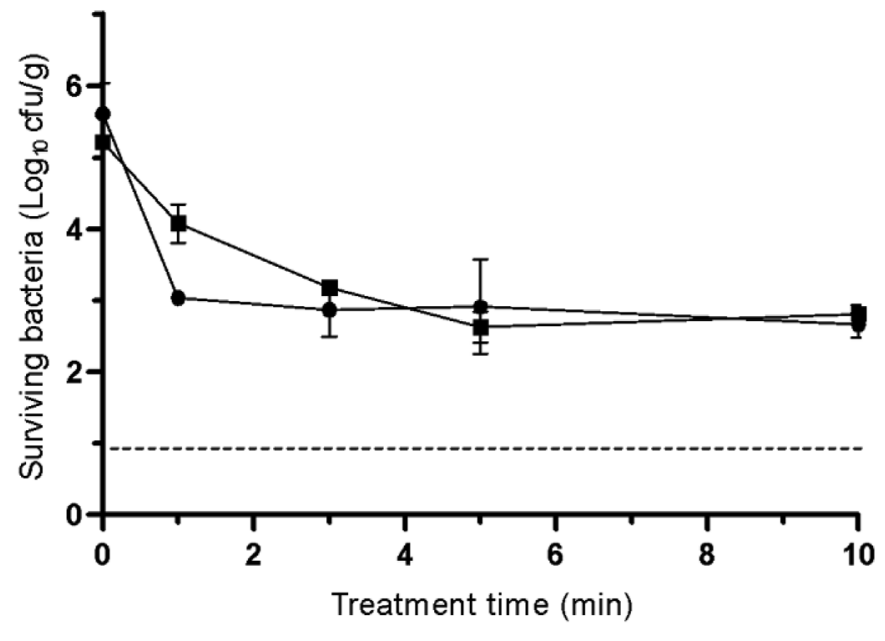

(a)

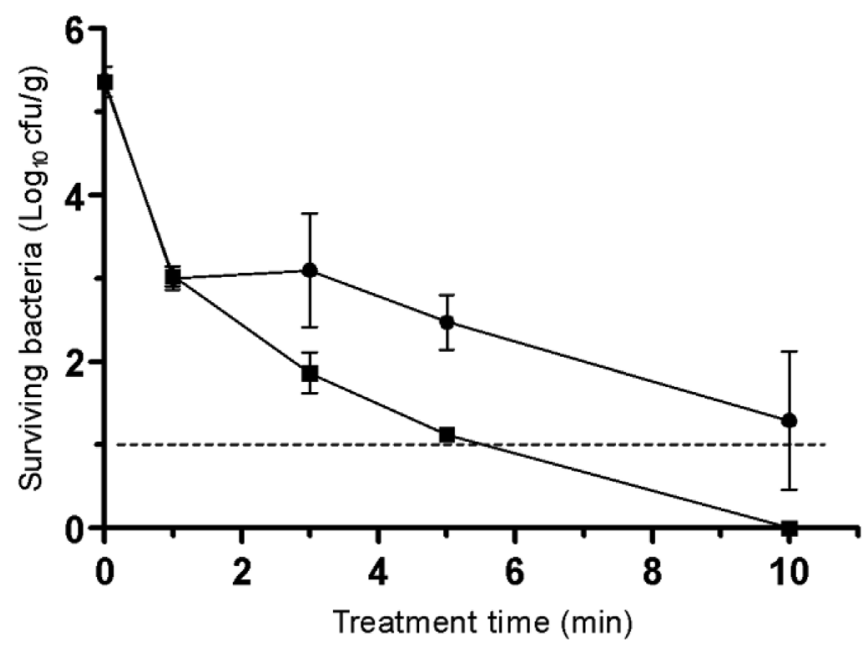

(b)

Fig. 11. Effect of (O) NaOCl or ( 1 ) ACP treatment on (a) L. innocua and (b) $P$. fluorescens inoculated on lettuce. Dotted line indicates detection limit (1.0 Log $\mathrm{CFU} / \mathrm{g}$ ). Vertical bars indicate standard deviation.

continuous monitoring and dosing. Plasma functionalised water achieved control comparable to chlorine treatment of $L$. innocua, but eradicated $P$. fluorescens populations below the detection limit, offering a potential for delayed spoilage and shelf-life improvement. In addition, micro-bubbling of the plasma effluent and high speed agitation helped distribute RONS, providing greater microbial reactive species interactions.

\section{Conclusions}

The efficacy of ACP to inactivate microbial load treatment depends on many factors, for example, the target microorganism, product type, $\mathrm{pH}$ of wash water and contact time of treatment. These findings demonstrate aqueous plasma treatment can effectively reduce viable counts of pathogenic and spoilage micro-organisms attached on lettuce. ACP functionalised water was efficient to control $L$. innocua while reducing $P$. fluorescens population below detection limit from lettuce, as well as from the wash water used for the treatment. In addition, microbubble and high speed agitation aided distribution of the active agents and enhanced microbial: reactive species interactions.

The fresh produce industry currently lacks an effective control method to ensure removal or elimination of food-borne microorganisms 
from fresh or minimally processed fruits and vegetables, which is compounded by increasing consumer concerns with standard chemicals including chlorine. Extending the safe shelf life of minimally processed fresh produce is of paramount importance to promote increased safe consumption and consumer confidence, pre-washing the fresh cut lettuce in plasma functionalised water could be an efficient replacement or additional technology for commercial processing lines. It would be anticipated that in scaled up and continuous systems, the concentration of organic debris, both particulate and dissolved may interfere with the action of plasma functionalised water; physical removal of particulate matter in addition to inline conductivity measurements could be useful approaches to retain water efficacy and reusability. Moreover, ACP shows potential for improving water recycling by minimizing contaminant load in wastewater. Thereby, significantly lowering the consumption of free chlorine and organic chlorine residues in the wastewaters.

\section{Acknowledgments}

This work has emanated from research supported in part by a research grant from Science Foundation Ireland under the Grant Number SFI/16/BBSRC/3391 and the BBSRC under the Grant Reference BB/ P008496/and the Food Institutional Research Measure (FIRM) administered by Department of Agriculture, Food and the Marine, Ireland (DAFM 13/F/444). The authors thank Dr. Ian Reid for the scanning electron microscopy imaging.

\section{Appendix A. Supplementary data}

Supplementary data to this article can be found online at https:// doi.org/10.1016/j.fm.2019.05.010.

\section{References}

APHA, A.W., 2012. Standard Methods for Examination of Water and Wastewater, 22nd ed. Washington: American Public Health Association, Standard Methods. 978 087553-013-0.

Bader, H., Hoigne, J., 1981. Determination of ozone in water by the indigo method; a submitted standard method. Ozone Sci. Eng. https://doi.org/10.1080/ 01919518208550955.

Barth, M., Hankinson, T.R., Zhuang, H., Breidt, F., 2009. Microbiological spoilage of fruits and vegetables. In: Compendium of the Microbiological Spoilage of Foods and Beverages, https://doi.org/10.1007/978-1-4419-0826-1_6.

Beuchat, L.R., 1998. Surface decontamination of fruit and vegetables eaten raw: A review. Food Saf. Unit World Heal. Organ. WHOFSFFOS982. https://entity/mediacentre/ factsheets/fs399/en/index.html.

Bourke, P., Ziuzina, D., Han, L., Cullen, P.J., Gilmore, B.F., 2017. Microbiological interactions with cold plasma. J. Appl. Microbiol. https://doi.org/10.1111/jam.13429.

Cubas, A.L.V., Machado, M.M., Pinto, C.R.S.C., Moecke, E.H.S., Dutra, A.R.A., 2016. Biodiesel production using fatty acids from food industry waste using corona discharge plasma technology. Waste Manag. https://doi.org/10.1016/j.wasman.2015. 05.040.

den Bakker, H.C., Cummings, C.A., Ferreira, V., Vatta, P., Orsi, R.H., Degoricija, L., Barker, M., Petrauskene, O., Furtado, M.R., Wiedmann, M., 2010. Comparative genomics of the bacterial genus Listeria: Genome evolution is characterized by limited gene acquisition and limited gene loss. BMC Genomics. https://doi.org/10.1186/ 1471-2164-11-688.

EFSA, 2017. The European Union summary report on trends and sources of zoonoses, zoonotic agents and food-borne outbreaks in 2016. EFSA J 15, 228. https://doi.org/ 10.2903/j.efsa.2017.5077.

Ercan, U.K., Wang, H., Ji, H., Fridman, G., Brooks, A.D., Joshi, S.G., 2013. Nonequilibrium plasma-activated antimicrobial solutions are broad-spectrum and retain their efficacies for extended period of time. Plasma Process. Polym. https:// doi.org/10.1002/ppap.201200104.

Gil, M.I., Selma, M.V., López-Gálvez, F., Allende, A., 2009. Fresh-cut product sanitation and wash water disinfection: Problems and solutions. Int. J. Food Microbiol. https:// doi.org/10.1016/j.ijfoodmicro.2009.05.021.

Glaser, P., Frangeul, L., Buchrieser, C., Rusniok, C., Amend, A., Baquero, F., Berche, P., Bloecker, H., Brandt, P., Chakraborty, T., Charbit, A., Chetouani, F., Couvé, E., De Daruvar, A., Dehoux, P., Domann, E., Domínguez-Bernal, G., Duchaud, E., Durant, L., Dussurget, O., Entian, K.D., Fsihi, H., Garcia-Del Portillo, F., Garrido, P., Gautier, L., Goebel, W., Gómez-López, N., Hain, T., Hauf, J., Jackson, D., Jones, L.M., Kaerst, U., Kreft, J., Kuhn, M., Kunst, F., Kurapkat, G., Madueño, E., Maitournam, A., Mata Vicente, J., Ng, E., Nedjari, H., Nordsiek, G., Novella, S., De Pablos, B., Pérez-Diaz, J.C., Purcell, R., Remmel, B., Rose, M., Schlueter, T., Simoes, N., Tierrez, A., Vázquez-
Boland, J.A., Voss, H., Wehland, J., Cossart, P., 2001. Comparative genomics of Listeria species. Science 80. https://doi.org/10.1126/science.1063447.

Guo, J., Huang, K., Wang, J., 2015. Bactericidal effect of various non-thermal plasma agents and the influence of experimental conditions in microbial inactivation: A review. Food Control. https://doi.org/10.1016/j.foodcont.2014.09.037.

Han, L., Boehm, D., Milosavljević, V., Amias, E., Cullen, P., 2016. Atmospheric cold plasma interactions with modified atmosphere packaging inducer gases for safe food preservation. Innov. Food Sci. Emerg. Technol. https://doi.org/10.1016/j.ifset.2016. 09.026.

Ikawa, S., Kitano, K., Hamaguchi, S., 2010. Effects of pH on bacterial inactivation in aqueous solutions due to low-temperature atmospheric pressure plasma application. Plasma Process. Polym. https://doi.org/10.1002/ppap.200900090.

Inatsu, Y., Kitagawa, T., Nakamura, N., Kawasaki, S., Nei, D., Bari, M.L., Kawamoto, S., 2013. Effectiveness of stable ozone microbubble containing water on reducing bacteria load on selected leafy vegetables. Acta Hortic. (Wagening.). https://doi.org/10. 3136/fstr.17.479.

Joshi, S., Cooper, M., Yost, A., Paff, M., Ercan, U.K., Fridman, G., Friedman, G., Fridman, A., Brooks, A.D., 2011. Nonthermal dielectric-barrier discharge plasma-induced inactivation involves oxidative DNA damage and membrane lipid peroxidation in Escherichia coli. Antimicrob. Agents Chemother. https://doi.org/10.1128/AAC. 01002-10.

Kim, J.-G., Yousef, A.E., Chism, G.W., 1999. Use of ozone to inactivate microorganisms on lettuce. J. Food Saf. https://doi.org/10.1111/j.1745-4565.1999.tb00231.x.

Liao, X., Liu, D., Xiang, Q., Ahn, J., Chen, S., Ye, X., Ding, T., 2017. Inactivation mechanisms of non-thermal plasma on microbes: A review. Food Control. https://doi. org/10.1016/j.foodcont.2016.12.021.

Lu, P., Boehm, D., Bourke, P., Cullen, P.J., 2017. Achieving reactive species specificity within plasma-activated water through selective generation using air spark and glow discharges. Plasma Process. Polym., e1600207. https://doi.org/10.1002/ppap. 201600207.

Lukes, P., Dolezalova, E., Sisrova, I., Clupek, M., 2014. Aqueous-phase chemistry and bactericidal effects from an air discharge plasma in contact with water: Evidence for the formation of peroxynitrite through a pseudo-second-order post-discharge reaction of H2O 2 and HNO2. Plasma Sources Sci. Technol. https://doi.org/10.1088/09630252/23/1/015019.

Ma, R., Wang, G., Tian, Y., Wang, K., Zhang, J., Fang, J., 2015. Non-thermal plasmaactivated water inactivation of food-borne pathogen on fresh produce. J. Hazard Mater. https://doi.org/10.1016/j.jhazmat.2015.07.061.

Mai-Prochnow, A., Clauson, M., Hong, J., Murphy, A.B., 2016. Gram positive and Gram negative bacteria differ in their sensitivity to cold plasma. Sci. Rep. https://doi.org/ $10.1038 /$ srep38610.

Martínez-Hernández, G.B., Navarro-Rico, J., Gómez, P.A., Otón, M., Artés, F., ArtésHernández, F., 2015. Combined sustainable sanitising treatments to reduce Escherichia coli and Salmonella Enteritidis growth on fresh-cut kailan-hybrid broccoli. Food Control. https://doi.org/10.1016/j.foodcont.2014.07.029.

Marui, T., 2013. An Introduction to Micro/Ano-Bubbles and Their Applications. An Introd. To Micro/Ano-Bubbles Their Appl.

Møretrø, T., Langsrud, S., 2017. Residential bacteria on surfaces in the food industry and their implications for food safety and quality. Compr. Rev. Food Sci. Food Saf. https://doi.org/10.1111/1541-4337.12283.

Oehmigen, K., Hähnel, M., Brandenburg, R., Wilke, C., Weltmann, K.D., Von Woedtke, T., 2010. The role of acidification for antimicrobial activity of atmospheric pressure plasma in liquids. Plasma Process. Polym. https://doi.org/10.1002/ppap.200900077.

Oliveira, M.A. de, Maciel de Souza, V., Morato Bergamini, A.M., De Martinis, E.C.P., 2011. Microbiological quality of ready-to-eat minimally processed vegetables consumed in Brazil. Food Control. https://doi.org/10.1016/j.foodcont.2011.02.020.

Patange, A., Boehm, D., Giltrap, M., Lu, P., Cullen, P.J., Bourke, P., 2018. Assessment of the disinfection capacity and eco-toxicological impact of atmospheric cold plasma for treatment of food industry effluents. Sci. Total Environ. 631-632. https://doi.org/10. 1016/j.scitotenv.2018.02.269.

Sarangapani, C., Dixit, Y., Milosavljevic, V., Bourke, P., Sullivan, C., Cullen, P.J., 2017. Optimization of atmospheric air plasma for degradation of organic dyes in wastewater. Water Sci. Technol. 75, 207-219. https://doi.org/10.2166/wst.2016.471.

Satoh, K., MacGregor, S.J., Anderson, J.G., Woolsey, G.A., Fouracre, R.A., 2007. Pulsedplasma disinfection of water containing Escherichia coli. Jpn. J. Appl. Phys., Part 1 Regul. Pap. Short Notes Rev. Pap. https://doi.org/10.1143/JJAP.46.1137.

Schmidt-Bleker, A., Winter, J., Bösel, A., Reuter, S., Weltmann, K.-D., 2016. On the plasma chemistry of a cold atmospheric argon plasma jet with shielding gas device. Plasma Sources Sci. Technol. https://doi.org/10.1088/0963-0252/25/1/015005.

Schnabel, U., Sydow, D., Schlüter, O., Andrasch, M., Ehlbeck, J., 2015. Decontamination of fresh-cut iceberg lettuce and fresh mung bean sprouts by non-thermal atmospheric pressure plasma processed water (PPW). Mod. Agric. Sci. Technol. 1, 23-39. https:// doi.org/10.15341/mast(2375-9402)/01.01.2015/003.

Shimizu, T., Iwafuchi, Y., Morfill, G.E., Sato, T., 2011. Formation of thermal flow fields and chemical transport in air and water by atmospheric plasma. New J. Phys. https:// doi.org/10.1088/1367-2630/13/5/053025.

Soli, K.W., Yoshizumi, A., Motomatsu, A., Yamakawa, M., Yamasaki, M., Mishima, T., Miyaji, N., Honjoh, K.I., Miyamoto, T., 2010. Decontamination of fresh produce by the use of slightly acidic hypochlorous water following pretreatment with sucrose fatty acid ester under microbubble generation. Food Control. https://doi.org/10. 1016/j.foodcont.2010.02.009.

Sun, S.H., Kim, S.J., Kwak, S.J., Yoon, K.S., 2012. Efficacy of sodium hypochlorite and acidified sodium chlorite in preventing browning and microbial growth on fresh-cut produce. Prev. Nutr. Food Sci. 17, 210-216. https://doi.org/10.3746/pnf.2012.17.3. 210.

Suslow, T., 1997. Postharvest Chlorination: Basic Properties \& Key Points for Effective 
Distribution. University of California, Division of Agriculture and Natural Resourceshttps://doi.org/10.3733/ucanr.8003.

Thirumdas, R., Kothakota, A., Annapure, U., Siliveru, K., Blundell, R., Gatt, R., et al., 2018. Plasma activated water (PAW): Chemistry, physico-chemical properties, applications in food and agriculture. Trends Food Sci. Technol. https://doi.org/10. 1016/j.tifs.2018.05.007.

Traylor, M.J., Pavlovich, M.J., Karim, S., Hait, P., Sakiyama, Y., Clark, D.S., Graves, D.B., 2011. Long-term antibacterial efficacy of air plasma-activated water. J. Phys. D Appl. Phys. https://doi.org/10.1088/0022-3727/44/47/472001.

Van Haute, S., Sampers, I., Holvoet, K., Uyttendaele, M., 2013. Physicochemical quality and chemical safety of chlorine as a reconditioning agent and wash water disinfectant for fresh-cut lettuce washing. Appl. Environ. Microbiol. https://doi.org/10.1128/ AEM.03283-12.

Van Haute, S., Sampers, I., Jacxsens, L., Uyttendaele, M., 2015. Selection criteria for water disinfection techniques in agricultural practices. Crit. Rev. Food Sci. Nutr. https://doi.org/10.1080/10408398.2012.705360.

Vaz-Velho, M., Fonseca, F., Silva, M., Gibbs, P., 2001. Is Listeria innocua 2030c, a tetracycline-resistant strain, a suitable marker for replacing L. monocytogenes in challenge studies with cold-smoked fish? Food Control. https://doi.org/10.1016/ S0956-7135(01)00029-9.

Warriner, K., Huber, A., Namvar, A., Fan, W., Dunfield, K., 2009. Recent advances in the microbial safety of fresh fruits and vegetables. Adv. Food Nutr. Res. https://doi.org/ 10.1016/S1043-4526(09)57004-0.

Wei, W., Wang, X., Xie, Z., Wang, W., Xu, J., Liu, Y., Gao, H., Zhou, Y., 2017. Evaluation of sanitizing methods for reducing microbial contamination on fresh strawberry, cherry tomato, and red bayberry. Front. Microbiol. 9, 2397. https://doi.org/10. 3389/fmicb.2017.02397.

Ziuzina, D., Han, L., Cullen, P.J., Bourke, P., 2015. Cold plasma inactivation of internalised bacteria and biofilms for Salmonella enterica serovar Typhimurium, Listeria monocytogenes and Escherichia coli. Int. J. Food Microbiol. 210, 53-61. https://doi. org/10.1016/j.ijfoodmicro.2015.05.019.

Ziuzina, D., Patil, S., Cullen, P., Keener, K., Bourke, P., 2014. Atmospheric cold plasma inactivation of Escherichia coli, Salmonella enterica serovar typhimurium and Listeria monocytogenes inoculated on fresh produce. Food Microbiol. 42, 109-116. https://doi.org/10.1016/j.fm.2014.02.007. 